\title{
Recharge Potentials Mapping using Remote Sensing and GIS Techniques: Case of Shallow Aquifers in the Senegal River Delta
}

\author{
Moctar Diaw ${ }^{1 *}$, Ibrahima Mall ${ }^{1}$, Serigne Faye ${ }^{1}$ and Yves Travi \\ ${ }^{1}$ Département de Géologie, Faculté des Sciences et Technique, Université Cheikh Anta DIOP, Dakar, Sénégal \\ ${ }^{2}$ Univertsité d'Avignon et des pays de Vaucluse, Laboratoire d'Hydrogéologie, UMR1114 EMMAH, France
}

*Corresponding author: Moctar Diaw, Département de Géologie, Faculté des Sciences et Technique, Université Cheikh Anta DIOP, Dakar, Sénégal, Tel: 00221775786529/00221709733103; E-mail: mkdiaw@yahoo.fr, moctar.diaw@ucad.edu.sn

Received: 27 Sep, 2018 | Accepted: 03 Nov, 2018 | Published: 09 Nov, 2018

Citation: Diaw M, Mall I, Faye S, Travi Y (2018) Recharge Potentials Mapping using Remote Sensing and GIS Techniques: Case of Shallow Aquifers in the Senegal River Delta. J Environ Toxicol Stud 2(2): dx.doi.org/10.16966/2576-6430.117

Copyright: @ 2018 Diaw M, et al. This is an open-access article distributed under the terms of the Creative Commons Attribution License, which permits unrestricted use, distribution, and reproduction in any medium, provided the original author and source are credited.

\begin{abstract}
The objective of this paper is to assess potential recharge zones in the different shallow aquifers of the Senegal River delta face to major development challenges of irrigated agriculture and physical and environmental constraints (semi-arid climate, dam, management of hydrological reservoirs, etc.). This study based on a combination of remote sensing techniques and multi-criteria analysis of GIS has demonstrated that it has been possible to produce potential recharge maps by integrating different factors in GIS such as lithology, slope, land cover/land use, drainage network, irrigation network, and groundwater depth. These parameters controlling groundwater accumulation in the Senegal River Delta are evaluated in terms of 5 potentials classes namely: very good potentials, good, moderate, low and very low potentials. The resulting map, which has shown great efficiency in the evaluation of recharge potentials, reveals that classes of good and very good potential (representing respectively $22 \%$ and $4 \%$ of the area), are particularly observed in the alluvial plain on the rivers and the proximity of irrigated fields. Moderate and low classes which represent respectively $41 \%$ and $32 \%$ of the area are mainly observed in the dune formations and alluvial plain distant to recharge zones (rivers and irrigated fields). Very low potentials constitute $1 \%$ are located essentially in clayey cuvettes of the alluvial plain. The resulting map, which allows a qualitative and visual representation of their charge, has been validated by recharge rates estimated from water table fluctuation and by ages determined from the tritium $(3 \mathrm{H})$ activity in ground waters. Thus, results indicate that the areas with recharge classes estimated correspond also with potentials recharge mapped for example; areas with high recharge are also the ones with high recharge potential. They indicate that this mapping approach is very useful and valuable in identifying potentials recharge areas which can be an important element for groundwater resource management and their sustainable exploitation and identifying of favorable sites for the future well drilling project in this area.
\end{abstract}

Keywords: Potential recharge; Mapping; Remote sensing; GIS; Shallow aquifers; River delta, Senegal

\section{Introduction}

The Senegal River delta has been in a long period faced too many physical constraints due to sea-water intrusions across the river and inland and long periods of drought during two decades (19701990). Despite this, the area has always been inscribed in the central position of Senegalese agriculture challenges related to the richness of its ecosystems and high hydraulic and agricultural potentialities. This has justified the particular interest by authorities through numerous morpho-pedological studies and prospections missions [19] agronomic tests and development programs $[10,11]$ and geological and hydrogeological missions [12-22], to explore and promote efficient irrigated agriculture not depending on climatic extreme events. Today, with various successive missions and programs, the delta has more opportunities and serious assets to eliminate constraints of agriculture development (irrigation, gardening and greenhouse crops), in connection with dams installation and irrigation schemes expansion. Compared to the rest of the country, the river delta has become a great attraction for agro-industries and farmers and for people seeking more favorable living conditions [23]. In this zone, problems of high salinity, availability, and mobilization of groundwater resources to a correct fresh water supply have always been a major challenge for the population. Shallow aquifers are largely very unproductive and often very salty due to problems related to their marine origins $[8,9,14,24-27]$ and their low possibilities of recharges [28-34]. The objective of this paper is to evaluate the groundwater potential recharge of shallow aquifers in a context of Sahelian climate, irrigated agriculture development and dams construction which are veritable motors of change observed in the Senegal River Delta Hydrosystem (SRDH). The study was based on the combined application of remote sensing and GIS technologies to identify and map potential groundwater recharge in SRDH. GIS has emerged as a powerful tool for handling spatial data and decision making in several areas including geological and environmental fields. It is, in particular, 
a useful technique for analyzing and quantifying such multivariate aspects of groundwater occurrence. Remote sensing is one of the main sources of information about surface features related to ground water. Such information can be easily inputted to GIS environment for integration with others types of data followed by analysis [35]. Satellite images are increasingly used in ground water exploration because of their utility in identifying various ground features, which may serve as either director indirect indicators of the presence of ground water $[36,37]$. Integration of the two technologies has proven to be an efficient tool in earth sciences (geology, mine, geomorphology, hydrogeology, civil engineering, geography,etc.) and in management and monitoring of natural resources [38]. It has become one of the leading tools in the field of hydrogeological science, which helps in assessing, monitoring and conserving groundwater resources $[39,40]$. Actually, with space technology advances and high-performance computers advent techniques for potential groundwater resources assessing have evolved. It has become important in prospect hydrogeology studies [41-47]; in mapping groundwater potentials zones and in delineation of groundwater reservoir [39,48-52] but also in studies of aspects and issues related to groundwater [53-55]. In addition, many researchers apply these techniques, increasingly using the GIS platform and its possibilities for multi-criteria analysis, in order to evaluate potential zones of aquifers and to model groundwater resources potentials [56-66]. The assessment process includes the collection of remote sensing data from appropriate sensors and the selection of factors that control the occurrence and movement of groundwater. Thus, many factors have been integrated in GIS and remote sensing techniques such as climate conditions, geology, structural condition, lithology, geomorphology including topography, soil types, land use/land cover, drainage network, vegetation, irrigated field, surface and groundwater flow conditions [35,40,49,51,52,67,68].

These various data are prepared in the form of thematic maps using geographical information system (GIS) software tool. These thematic maps are then integrated using "Spatial Analyst" tool and processed according to their groundwater accumulation contribution with appropriate weighting. The "Spatial Analyst" tool with mathematical and Boolyan operators is then used to develop models depending on the objectives of the problem at hand.
In addition to the possibility of manipulation and analysis of individual layer of spatial data. GIS is used to analyze and model the interrelationship between thematic layers and to assess groundwater potential zones. Whereas field studies or conventional methods of hydrogeological surveys help to further validate results. In this study, the multicriteria analysis approach of GIS has been used to assess their charge potential of shallow aquifer in Senegal River delta. The model results, that can have great potential for use in groundwater management, have been efficiently validated by recharge ratio and calculated to groundwater fluctuation level. Moreover, groundwater age was estimated by tritium, which has provided a rapid and cost-effective delineation of groundwater recharge potential zones.

\section{Physical and Geological Settings}

SRDH is a geographical unit which is part of the downstream portion of the large hydrological basin of Senegal River. It is mainly limited and influenced by the Atlantic Ocean in the West, in the North by the great desert region of Trarza (Mauritania), in the East and in the South by the large arid region of Ferlo (Figure 1). The climate is characterized by a Sahelian regime. The annual cycle of precipitation is unimodal and is characterized by a long dry season ( 8 months) and a wet season (4 months). The average rainfall varies between 200 and $400 \mathrm{~mm} /$ year. The evaporative demand, which varies between 6 to 7 $\mathrm{mm} \mathrm{day}^{-1}[69]$, provokes deficit in the water balance $\left(8-30 \mathrm{~mm} \mathrm{day}^{-1}\right)$. This zone is geomorphologically constituted essentially by:

- An alluvial plain (low land) fed by a very dense hydrographic network dominated by the Senegal river and it's multitudes arms of effluents which in turn feed natural cuvettes, creeks and ponds located in the floodplains. The soils are more or less halomorphic and hydromorphic with silty clay texture; the hydromorphic vertic soils are observed in clay settling basins. They are made of massive structure very poor in organic matter and are very suitable for irrigated rice cultivation. They are the support of hydro-agricultural development and represent more than $65 \%$ of the potential of the irrigable land.

- Dune formations with variable altitude $(4-40 \mathrm{~m})$ constituted by brown soilsorred-brown isohumic soils that develop an arid ecosystem (Figure 1).

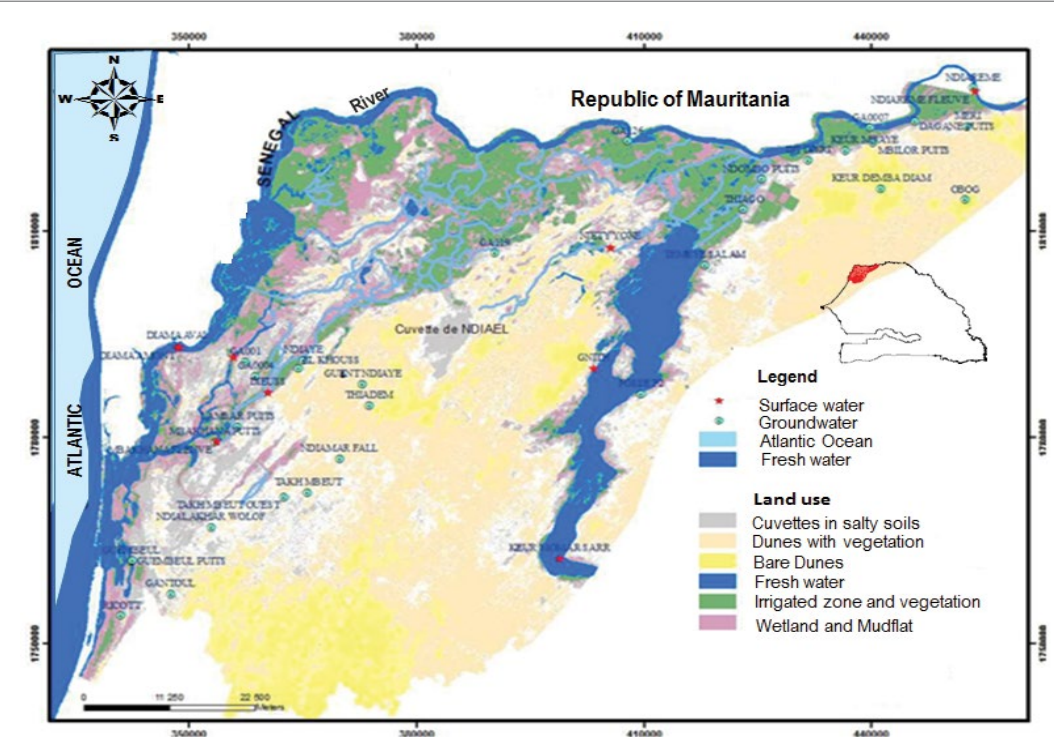

Figure 1: Land use map and location of sampling site in SRDH (drawn from LANDSAT.2013 image). 
These dunes have been deposed after a long period of marine regression $(-100 \mathrm{~m})$, where the arid climate and the action of continental trade winds favored the formation of "reddunes" oriented NNESSW. Sediments constituted of Aeolian sands have been dated to the Ogolian period [70]), especially during the last glacial stage (2500018000 BP years). They have thicknesses varying between 8 and $9 \mathrm{~m}$ and rest unconformably on various substrates (Figure 2). These deposits are characterized by allowing water retention capacity a light texture and a good aeration, which explains their general cultivation. They can support all types of crops other than rice (gardening, greenhouse crops for horticulture, etc.). Generally, aeolian sands contain a freshwater aquifer and can be salty when it is in contact with salt deposits attributed to the Inchirian witness of the period when the delta was covered by the sea (inter-dune).

After the great regressive phase of Ogolian, especially during the Holocene, River Delta experienced marine transgressions series that have set up successive marine deposits observed invariant levels +1 to +12 m NGI (National Geographic Institute). Thus, transgressive marine episodes during the Nouakchottian (6800 to 4200 BP years), especially during the Flandrian (around 5500 BP years), determined morphosedimentary aspects of current Delta and its alluvial plain. Alluvial plain deposits characterized by a varied nature are often detrital and anarchic due to multiple variations of fluviatile and eustatic levels and climate condition of the zone [71]. It is covered with generally clayey or clay silty layers of post-Nouakchottian which are characterized by a very low percolation index or good retention capacity $[72,73]$ and some hydromorphy degree [7]. Alluvial plain encloses a shallow aquifer contained in Nouakchottian (upper compartment) remained layers relatively homogeneous vertically and spatially which are regularly belong the class of fine-grained sand and silts, ranging in thickness from 4 to $16 \mathrm{~m}$. The aquifer reservoir, sometimes confined (WestSouth-West sector) or semi-confined (East-North-East sector), has sediment in the marine or lagoon environment, thus trapping many salts during their setup; $[6,14,22]$. Ground waters are sometimes very salty and are often found at levels $-2.00 \mathrm{~m}$ NGI, which makes it very sensitive to environmental and hydro-climatological conditions but especially to socioeconomic context dominated by current irrigated agriculture development.

\section{Data used and Methodology}

\section{Hydrogeology}

Two campaigns were carried out to measure piezometric levels in situ and to take water samples from the alluvial plain and dune formations for isotopic analysis, occurring a network of 34 points. For piezometric variations monitoring, twenty-four points were selected on the basis of complete and regular data series. The choice of these points, especially in the alluvial plain, was also guided by their location in relation to irrigation schemes, hydraulics axis itself and groundwater level collected (upper compartment of the shallow aquifer). Piezometric fluctuations data used were taken between July 2012 and November-December 2013 respectively in dry and wet seasons, to be able to estimate the average recharge. The recharge in both aquifer units is calculated from the following formula:

$$
R=S y \cdot \frac{d h}{d t}
$$

Where $S y=$ Specific storage coefficient, $h=$ piezometric variation level and $t=$ time. In the area, we considered respectively $20 \%$ and $10 \%$ as the mean representative values for $S y$ or porosity in dunes and alluvial plain [22]. Groundwater tritium activities sampled in NovemberDecember 2013 were analyzed by hydrogeology laboratory in Avignon University. The radioactive isotope of the water molecule $\left({ }^{3} \mathrm{H}\right.$, tritium) emits radiation whose intensity decreases with the time that can be measured using very sensitive methods and specialized instruments for counting (spectrometer of mass) [74]. The tritium contents were determined firstly by distillation of the initial solution to reduce the inorganic salts, then by electrolytic enrichment before being switched to liquid scintillation counting [75]. It is expressed in tritium units (UT) and the analytical uncertainty is 0.7 UT. In order to determine the recharge contribution and origin, a calculation of the groundwater

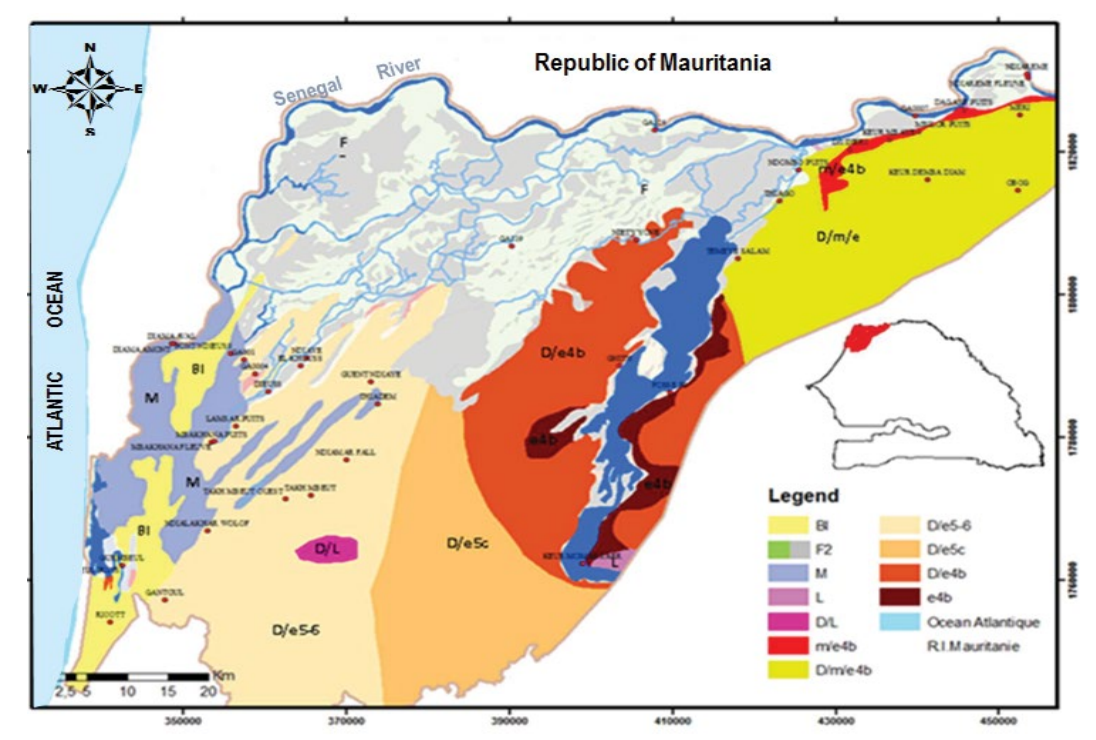

Figure 2: Geological map of SRDH (PASMI,2009).

*Bl: Coastal strip; *M:deltaic formation with vases and mudflats; *F2: recent fluvial lagoons; *L: lacustrine formation; D/L: Dune/lacustrine limestones; *m/e4b: Miocene/Ypresian formations; *D/m/e4b: Dune/Miocene/Lower Eocene-Ypresian; *D/e5-6: Middle/LutetianDune/Eocene; *D/e5c: Upper Eocene Dune; *D/e4b: Dune/Lower Eocene-Ypresian; *e4b: Lower Eocene-Ypresian. 
age was realized. The groundwater dating method is based on the measurement of tritium activity $\left(A_{t}\right)$ in each hydrogeological unity, $A_{t}$ depends only on its decay constant $(\lambda)$ and time $(\mathrm{t}): A(t)=A_{0} \cdot e^{-\lambda t}$

$$
t=-17.93 \cdot \ln \left(\frac{A^{t}}{A^{0}}\right)
$$

Where $\mathrm{A}$ is the activity of ${ }^{3} \mathrm{H}$ at time $t ; A_{0}$ is the initial activity (usually tritium contents for rainwater and $\lambda$ the disintegration constant:

$$
\lambda=\frac{\ln 2}{t_{1 / 2}}
$$

Where $t_{1 / 2}=12.26$ years, which represents half-life time. In a simple approach, the recharge can be estimated as:

$$
R=\sum n i \cdot H i / T
$$

Where $T$ is the average residence time (derived from the exponential model); $n i$ the porosity and $H i$ the thickness of the aquifer that considers the vertical between the surface and the saturated zone.

\section{Cartography}

LANDSAT8 scenes were acquired in March 2013 and used for land use mapping purposes. Satellite images data used that cover the Senegal River delta were obtained by downloading

From the USGS website (http://ita.cr.usgs.gov/earth_explorer). After downloading, different images scenes of LANDSAT8 $(30 \mathrm{~m}$ resolution) were geometrically rectified to be brought into conformity with the geographical reality, in a geodesic system WGS84, with a further projection to the 28 North zone UTM system. These geometric corrections were made in the software ArcMap9.3, in order to obtain a geo-referenced image prior to classification and drawing a land use map. The process consisted of extracting information from the images in order to structure them for the purposes of analysis and integration into a GIS. ASTER images ( $30 \mathrm{~m}$ resolution) were also used. These elevation images were received as a series of split images on NGA (National Geospatial-Intelligence Agency) and NASA
(National Aeronautics and Space Administration) sites. They were then assembled by mosaicing and then processed using ArcMap software 9.3 (projections in WGS84 geodetic and UTM systems). This software contains topography optimization modules and interactive mapping of the features contained in the projected image. The ASTER image processing, in the hydrology module of the Spatial Analyst tool, allowed to generate relief, land geomorphology, and restore slopes that were calculated in the "Slopesub-menu" and to extract the drainage network. The network drainage extraction was done in two steps, respectively by using "Flow direction" and "Flow accumulation" menus into "spatial analyst" tool which is one of the key tools to extract surface hydrological characteristics. The tool, which considers the relief as an input parameter, generates an output raster that shows flow directions in each cell of the raster and evaluates the flows accumulation as form cumulative weights off lows at each pixel of the output raster. In fact, it is the output data from the ASTER images processing (drainage network and slope), which are combined in the model with other parameters that also affect potential groundwater accumulation. Such as soils types, land use (extraction of irrigated areas from LANDSAT image processing) and hydrogeological parameters of the aquifer, particularly groundwater depths [76]. Sukhija, et al. [77], to evaluate recharge potential in the alluvial land dune aquifers of the Senegal River Delta.

\section{Model data}

The integrated approach of remote sensing and GIS techniques has become a liable tool for producing valuable data used in recharge conceptual model or for determining sources of recharge in a site. Thus, a systematic integration of data related to physical and dynamic characteristics of the site with those classical hydrogeological investigations give very efficient and precious indications on evaluating recharge potential zones in the shallow aquifers of SRDH. The most determining data of the model are:

Soils types: The soil types can be an important factor in the establishment of groundwater accumulation. The environment largely determines type and pattern soils alterations (Figure 3). Thus, it

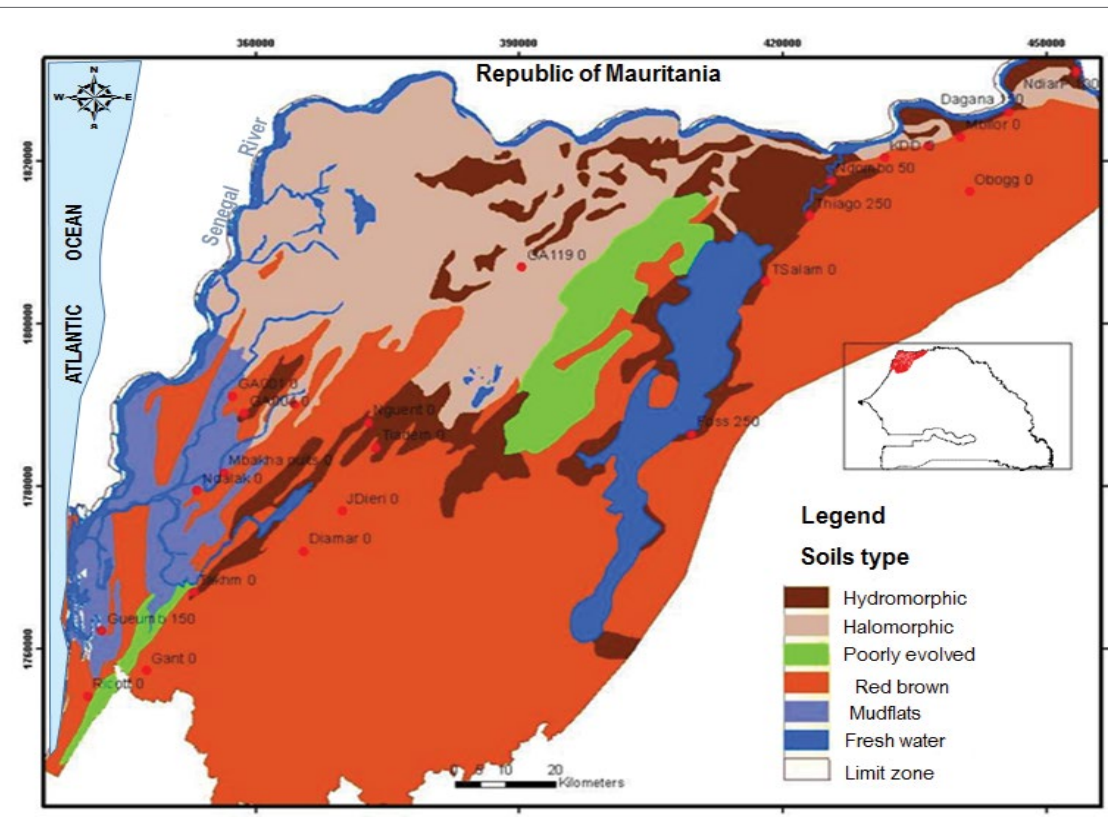

Figure 3: Soils type distribution in SRDH. 
develops soils in the alluvial plain halomorphic that are characterized by their compaction and high clay content compared with other soils types. These halomorphic soils could present a bad infiltrability potential and therefore a bad capacity to set up a groundwater stock. Hydromorphic rocks with a lower percentage of clay may have a low infiltration potential. On the other hand, the most interesting potentials are observed in the dune formations and in the poorly evolved soils. These sandy soils nature may have good potential for infiltration into groundwater. Silt-clay-sandy mud flats may have rather a moderate potential.

Slope land: Renewal of groundwater is generally inversely proportional to the slope. The alluvial plain that occupies most of the delta is relatively flat, whilst often marked by small undulations with low altitudes and slopes between $0-10 \%$. This configuration type makes it more suitable for infiltration than for runoff, which is, therefore, more favorable for groundwater renewal if we take into account these low slope values $(0-10 \%)$, also observed in the inter-dunes. We can observe the opposite effect especially in the dunes which have much higher altitudes. The slopes are particularly variable in this part. They can reach slopes ranging from 20 to $40 \%$ and sometimes $90 \%$ (Figure 4). These orders of magnitude are also observed in the transition zone between dunes and the alluvial plain where we observe some dune-hill (dune cluster) relics on which relatively lower slopes values with for the most part, which is between $10-20 \%$.

Groundwater depth: The groundwater renewal is also inversely proportional to the aquifer depth, which is generally quite low in the alluvial plain $(<6 \mathrm{~m})$ and relatively high in the Ogoli and Une Formations where they can reach up to $20 \mathrm{~m}$ (Figure 5). This is an important parameter to set up groundwater stocks related to high water evaporation that influences infiltration or percolation rates to the water table.

Network drainage: The hydrographic network, which is also an essential element in groundwater reserves, is closely linked to physiographic and geographical factors of the environment. Distances to the river are inversely proportional to recharge. In the study area, the flat topographic conditions and the presence of a rather dense network in the alluvial plain contribute to recharge areas favorable, especially in the adjacent areas or bordering hydraulic axes (Figure 6). In these areas, lateral extensions of the recharge are often limited by clay texture of the surface sediments on their borders.

Network irrigation: Is an important parameter in groundwater stock in the Senegal River delta. However, it is closely related to soils type, irrigation mode and frequency, and aquifer characteristics. Furthermore, to the alluvial plain, flat topographic conditions and low slope land, which favors infiltration rather than runoff, accentuated groundwater potential accumulation, especially in an area close to irrigated zones (Figure 7).

All of these input data have been generated, reclassified, and weighted. Their classification tools provide an effective means for calculating the conversion. Each class value in an input raster was assigned a new value based on an evaluation scale ranging from 1 to 9 . These new values were calculated from the values of the original input raster. Each input raster was weighted according to its importance or percentage of influence in setting up groundwater reserves. Thus, the weight is a relative percentage, and the sum of the percentages of weight influence must be equal to 100 . The modification of the rating scales or percentages of influences may change the results of the weighted superposition analysis [78]. Thus, to determine the weights and percentages of influences of each parameter, we first carried out a statistical analysis using the software R3.2.1. This analysis takes into account the input parameters of the model as well as the recharge rate calculated from piezometric fluctuations (Table 1). Thus, recharge is chosen as a dependent variable and other parameters (slopes land, soil types, distance to the nearest river, distance to the nearest irrigated zone and aquifers depth) as explanatory variables. The results of this statistical test show that the quantitative variables have low probability thresholds (>0.05) with very variable test values (Table 2 ).

These test values define the importance of each parameter in the establishment of groundwater reserves. In order of importance, parameters that most influence recharge are: groundwater depth,

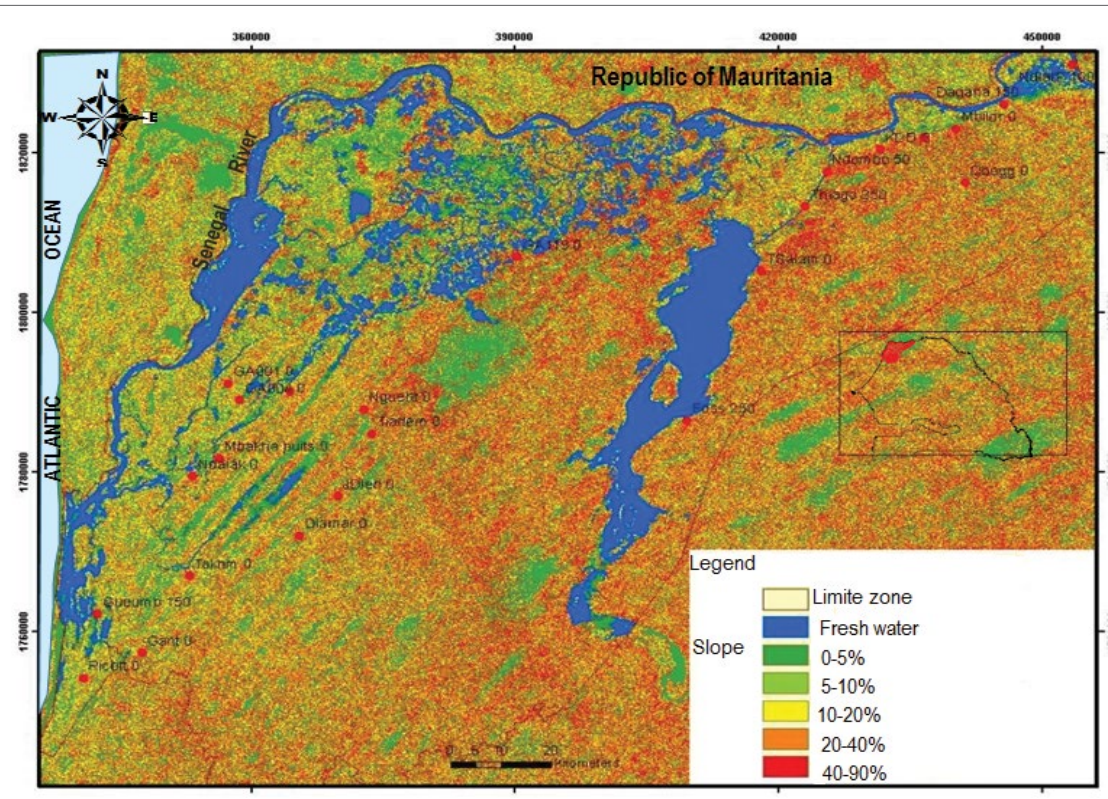

Figure 4: Slope Map in SRDH (extract to ASTER image). 
Table 1: Statistics of Input parameters into the model.

\begin{tabular}{|c|c|c|c|c|c|c|}
\hline Nom & $\begin{array}{l}\text { Recharge/Piezometric } \\
\text { fluctuation }\end{array}$ & Groundwater depth & $\begin{array}{l}\text { Distance to the Nearest } \\
\text { irrigated zone }\end{array}$ & $\begin{array}{l}\text { Distance to the } \\
\text { nearest river }\end{array}$ & Soils type & Slope \\
\hline Dagana & 45 & 4.19 & 150 & 800 & HY & 10 \\
\hline Ndiareme Puits & 82.5 & 3.08 & 100 & 100 & HY & 20 \\
\hline Mbilor & 19.5 & 4.35 & 158 & 951 & $\mathrm{RB}$ & 53.85 \\
\hline Keur Mbaye & 64.5 & 8.83 & 372 & 1300 & VE & 12 \\
\hline Ndombo & 118.5 & 4.04 & 50 & 100 & HY & 40.72 \\
\hline Thiago & 24 & 5.28 & 250 & 100 & HY & 30.53 \\
\hline Temeye Salam & 48 & 3.38 & 170 & 400 & HY & 92.35 \\
\hline Foss village & 52 & 4.31 & 250 & 400 & HY & 14.56 \\
\hline Nguent & 7.5 & 2.6 & 5556 & 5960 & HY & 0 \\
\hline Tiadem & 12 & 1.6 & 10000 & 11375 & HY & 13.93 \\
\hline Gueumbeul & 57 & 2.38 & 150 & 100 & VA & 12.16 \\
\hline GA119 & 54 & 3.24 & 947 & 400 & VE & 47.20 \\
\hline GA001 & 60 & 3.68 & 1230 & 1780 & $\mathrm{RB}$ & 13.34 \\
\hline GA004 & 87 & 3.2 & 264 & 800 & $\mathrm{HY}$ & 2 \\
\hline Gantour & 62.5 & 8.95 & 1518 & 1585 & $\mathrm{RB}$ & 48.60 \\
\hline Ricott & 37.5 & 2.7 & 423 & 2066 & $\mathrm{RB}$ & 10.29 \\
\hline Obogg & 26.8 & 20.92 & 6792 & 8996 & $\mathrm{RB}$ & 0 \\
\hline Keur Demba Diam & 70 & 11.15 & 739 & 989 & $\mathrm{RB}$ & 97.49 \\
\hline JDieri & 19.4 & 13.43 & 5255 & 5360 & $\mathrm{RB}$ & 17.26 \\
\hline Diamar & 29.3 & 9.5 & 5240 & 5490 & $\mathrm{RB}$ & 0 \\
\hline Takhmbeut & 47.5 & 4 & 604 & 1084 & $\mathrm{HY}$ & 0 \\
\hline Ndalakhar & 60 & 6.07 & 271 & 400 & $\mathrm{RB}$ & 35.35 \\
\hline Mbakhana puits & 90 & 4.3 & 647 & 800 & VA & 15.81 \\
\hline Al khouss 2 & 37.5 & 10.22 & 357 & 600 & VE & 17.26 \\
\hline
\end{tabular}

*Soils_RB=red-brown soils, *Soils_VA=Mudflats; *Soils_Hy: hydromorphic Soil

Table 2: Results of linear regression of model.

\begin{tabular}{|c|c|c|c|c|}
\hline & Estimated & Standard Error & test Value & $\operatorname{Pr}(>|t|)$ \\
\hline (Interception) & $6.961 \mathrm{e}+01$ & $1.687 e+01$ & 4.126 & 0.000897 \\
\hline Groundwater depth & $-8.757 e+02$ & $9.371 \mathrm{e}+02$ & -0.934 & 0.364879 \\
\hline Distance to the nearest river & $-3.642 \mathrm{e}-03$ & $1.078 \mathrm{e}-02$ & -0.338 & 0.740118 \\
\hline Slope & $7.023 e-02$ & $2.280 \mathrm{e}-01$ & 0.308 & 0.762261 \\
\hline Distance to the nearest irrigated zone & $-2.349 e-03$ & $1.156 \mathrm{e}-02$ & -0.203 & 0.84166 \\
\hline Soil_RedB & $-6.807 e+00$ & $1.492 \mathrm{e}+01$ & -0.456 & 0.654647 \\
\hline Soil_Mud & $1.608 \mathrm{e}+01$ & $2.033 e+01$ & 0.791 & 0.441334 \\
\hline Soil_HY & $-1.049 e+01$ & $1.811 \mathrm{e}+01$ & -0.579 & 0.571164 \\
\hline
\end{tabular}

*Soils_RB=red-brown soils; *Soils_VA=Mudflats; *Soils_Hy: hydromorphic Soil

soils type, distance to the nearest river, slope land and distance to the nearest irrigated zone; with respectively test values of0.934.-0.636.-0.338.0.308 and-0.203. Thus, "test" values provide a percentage of influence or a weight which is attributed to each parameter.

For example, if we consider the depth of the water table which is the most important parameter in groundwater recharge, a weight of 9 is attributed to the class "very good potentiality" and its percentage of influence is equal to $34 \%$. In the case, class "very good potentiality" will have a relative weight of $9^{*} 0.34$ which is equal to 3.06 . The same operation was repeated for all classes of each parameter by multiplying its weight by its percentage of influence. Table 3 summarizes the factors and their weighting.
All these parameters were then evaluated into 5 potential classes, named: very good, good, moderate, low and very low; and weighted from 1 to 9. Then, integrated into the GIS, each raster map was reclassified into five potential classes. The weighted overlay analysis was carried out in "Spatial Analyst" module of Arc Map 9.3. This module is used to standardize, compare and combine the parameters chosen for the model. Thus, all thematic maps were reclassified before being integrated into the GIS, to generate a unique recharge potentialities map. Figure 8 summarizes data integration phases into the model for recharge potentialities of shallow aquifers in Senegal River Delta.

The flowchart presented in figure 9 shows all model steps that made possible the map of potential recharge zones as well as treatments carried out on the various data used in the multi-criteria analysis. 
Table 3: Classification of the factors involved in groundwater reserves and their percentage of influence (calculated by statistical analysis).

\begin{tabular}{|c|c|c|c|c|c|}
\hline Class Weighted Parameters & $\begin{array}{l}\text { Very good } \\
9\end{array}$ & $\begin{array}{c}\text { Good } \\
7\end{array}$ & $\begin{array}{l}\text { Moderate } \\
\quad 5\end{array}$ & $\begin{array}{c}\text { Low } \\
3\end{array}$ & $\begin{array}{l}\text { Very low } \\
1\end{array}$ \\
\hline $\begin{array}{l}\text { Ground water depth } \\
34 \%\end{array}$ & $\begin{array}{l}3.06 \\
1-5.7\end{array}$ & $\begin{array}{l}2.38 \\
5.7-7\end{array}$ & $\begin{array}{c}1.7 \\
7-10\end{array}$ & $\begin{array}{c}1.02 \\
10-15\end{array}$ & $\begin{array}{c}0.34 \\
15-21\end{array}$ \\
\hline $\begin{array}{l}\text { Soils type } \\
30 \%\end{array}$ & $\begin{array}{c}2.7 \\
\text { sands }\end{array}$ & $\begin{array}{l}2.1 \\
\text { Silty sand }\end{array}$ & $\begin{array}{l}1.5 \\
\text { Silt }\end{array}$ & $\begin{array}{c}0.90 \\
\text { Clay-silt }\end{array}$ & $\begin{array}{l}0.30 \\
\text { Clay }\end{array}$ \\
\hline $\begin{array}{l}\text { Distance to the nearest river (buffer) } \\
16 \%\end{array}$ & $\begin{array}{c}1.44 \\
0-200\end{array}$ & $\begin{array}{c}1.12 \\
200-400\end{array}$ & $\begin{array}{c}0.80 \\
400-600\end{array}$ & $\begin{array}{c}0.48 \\
600-800\end{array}$ & $\begin{array}{c}0.16 \\
800-10000\end{array}$ \\
\hline $\begin{array}{l}\text { Slope } \\
11 \%\end{array}$ & $\begin{array}{c}0.99 \\
0-5\end{array}$ & $\begin{array}{l}0.77 \\
5-10\end{array}$ & $\begin{array}{c}0.55 \\
10-20\end{array}$ & $\begin{array}{c}0.33 \\
20-40\end{array}$ & $\begin{array}{c}0.11 \\
40-90\end{array}$ \\
\hline $\begin{array}{l}\text { Distance to the nearest Irrigated zone (buffer) } \\
9 \%\end{array}$ & $\begin{array}{l}0.81 \\
0-50\end{array}$ & $\begin{array}{c}0.63 \\
50-100\end{array}$ & $\begin{array}{c}0.45 \\
100-150\end{array}$ & $\begin{array}{c}0.27 \\
150-200\end{array}$ & $\begin{array}{c}0.09 \\
200-250\end{array}$ \\
\hline
\end{tabular}

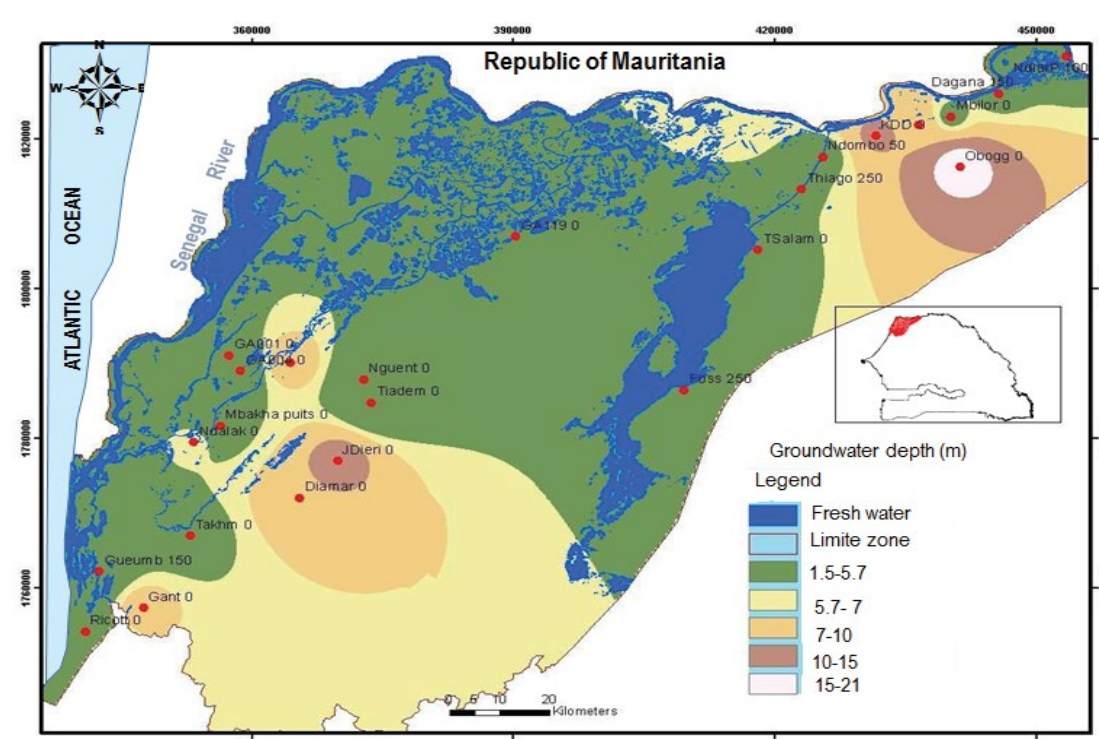

Figure 5: Slope Map in SRDH (extract to ASTER image).

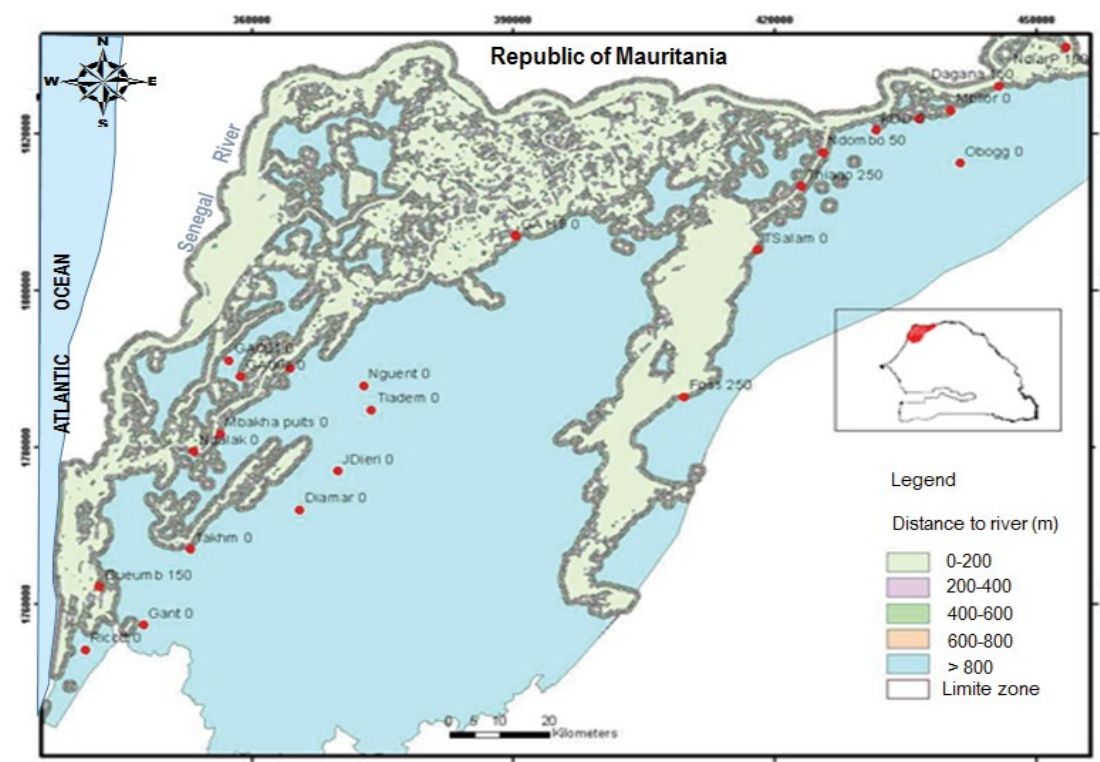

Figure 6: Distance to the nearest River (buffer) in SRDH. 


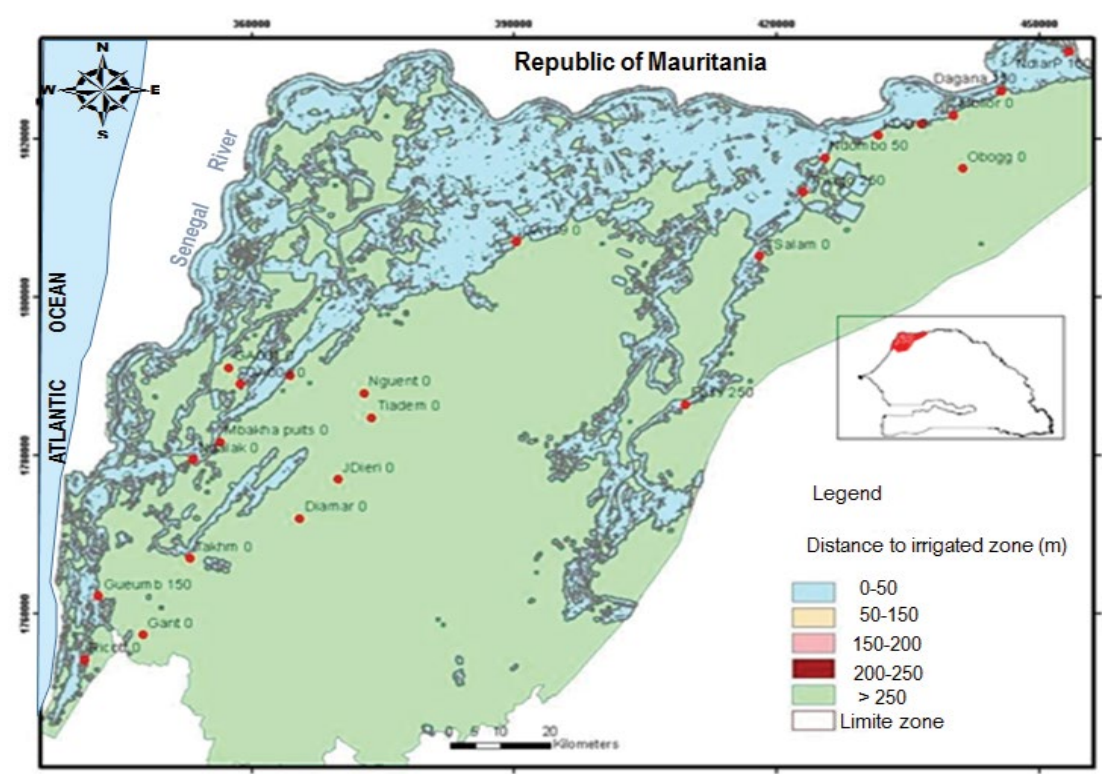

Figure 7: Distance to the nearest irrigated zone (buffer) in SRDH.

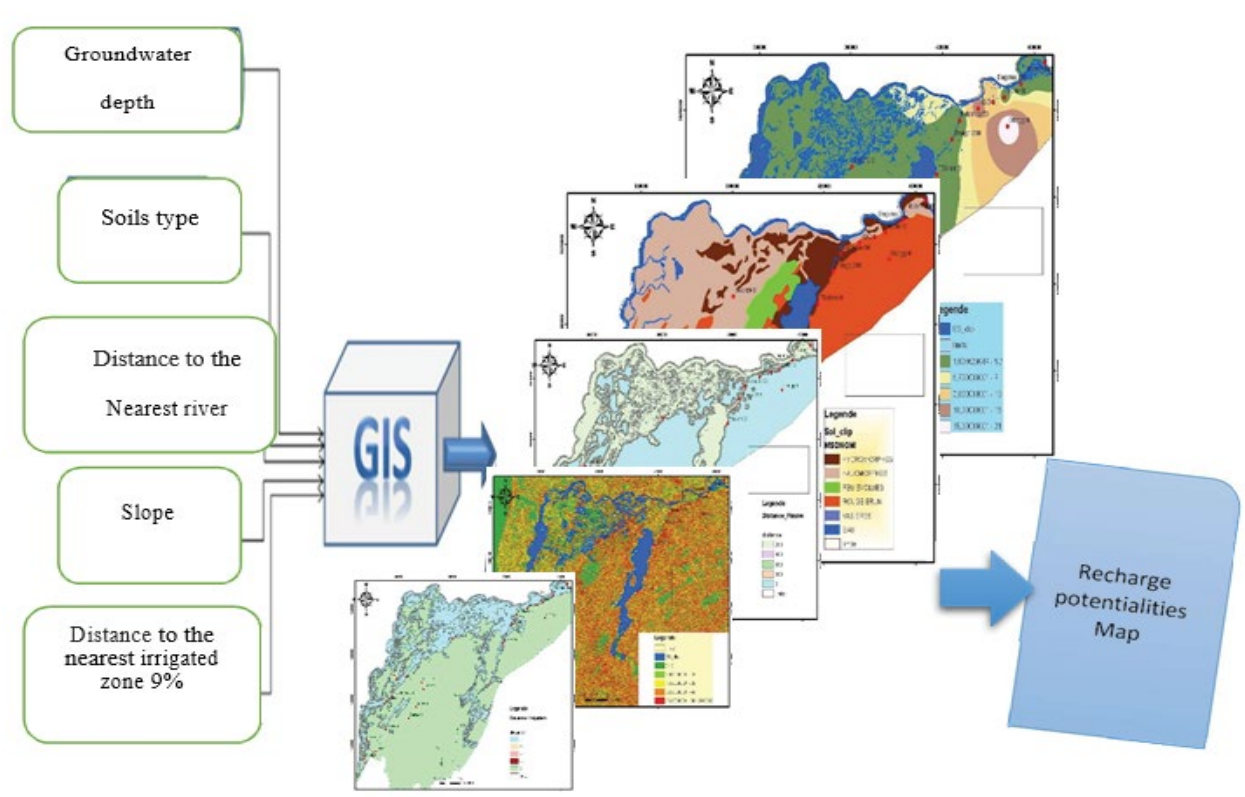

Figure 8: Flowchart of integrated parameters and weighting percentage.

\section{Results and Discussion}

The map of aquifer potential zones deduced from the GIS analysis by integration of the weighted parameters indicates five potentiality classes ranging from "very good potentialities" to "very low potentialities". The results of the cartographic method show that areas with very high and high recharge potential are mainly located in the alluvial plain especially along hydraulic axes and in areas nearest to hydroagricultural developments (Figure 10). These sectors, which therefore constitute privileged areas for alluvial aquifer recharge, represent $26 \%$ of the total area of the zone. Areas with very good potential occupy about $4 \%$, which represents about 24022 ha, while areas with good potential represent $22 \%$ or 119377 ha (Table 4 and Figure 10).
Table 4: Statistics of areas of potential classes.

\begin{tabular}{|c|c|c|c|}
\hline Classes & Area in hectare & Percentage (\%) & Classes of Recharge \\
\hline Class 1 & 5095.61 & 0.92 & Very low potentiality \\
\hline Class 2 & 177578.38 & 32.25 & Low potentiality \\
\hline Class 3 & 224429.61 & 40.76 & Moderate potentiality \\
\hline Class 4 & 119377.51 & 21.68 & Good potentiality \\
\hline Class 5 & 24022.10 & 4.36 & Very Good potentiality \\
\hline
\end{tabular}




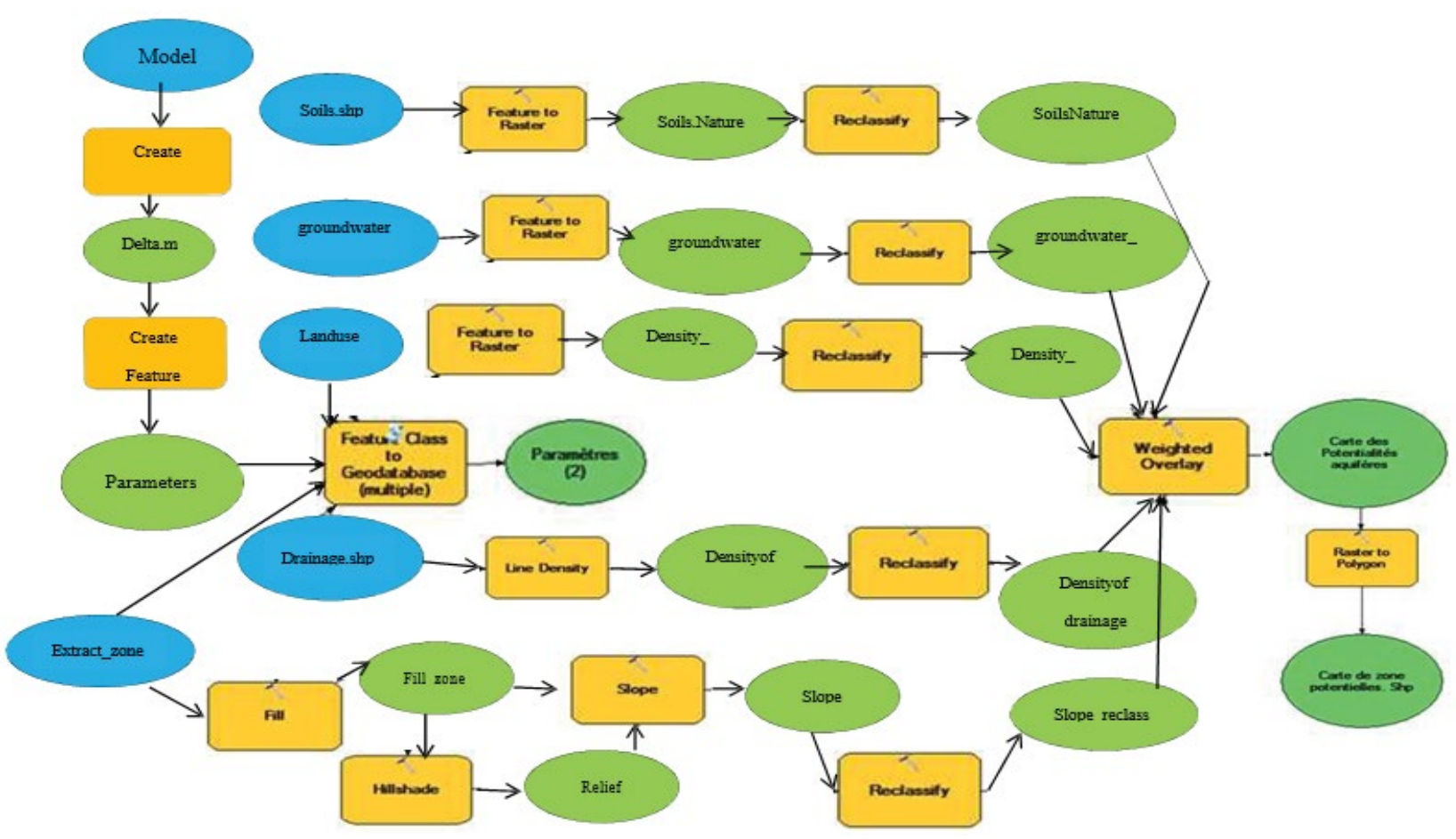

Figure 9: Model used for recharge potentialities mapping of shallow aquifers in SRDH.

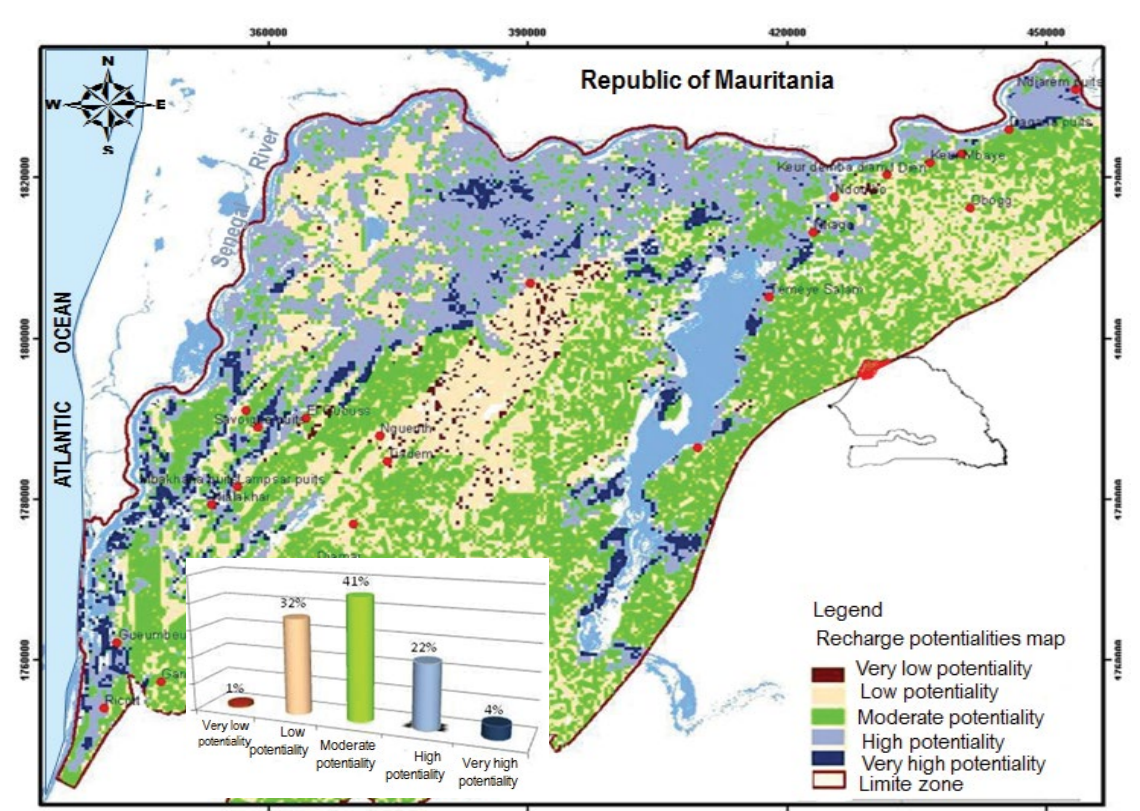

Figure 10: Recharge potentialities map in SRDH.

Very good and good potential areas are observed essentially in the alluvial plain particularly on semi-permeable terrain located in the northeast area. This situation could be related to groundwater recharge from flooding by irrigated activities and also by the proximity to major rivers (often much higher than $70-90 \mathrm{~mm} /$ year). But, also in major part of the alluvial plain, low and very low recharge potential rates have been observed (mainly in cuvettes zones) due to clayey soils types. The impermeability of these sediments, therefore, favors high evaporative rate in this part where water infiltration is less important. Areas with low potential areal so observed in the dune formations, particularly in the part where the thickness of the unsaturated zone (or sandy cover) is very important $(10 \mathrm{~m})$. In this situation, infiltrated waters are more exposed to evaporation phenomenon which can reduce highly recharge rate in this a ride ecosystem. This finding can also be justified by low recharge rates observed through quantitative approaches in these different sectors. However, areas with very low and low potential 
cover respectively 5095 ha and 177578 ha, representing $1 \%$ and $32 \%$ of the total surface. On the other hand, they overate potential is the class found mainly on dune formations and represents $41 \%$ of the total area, about 224430 ha. It is mainly accompanied in dunes by the low potential class, especially in steeply sloping areas where the thickness of the sand cover is more important. In this study, the quantitative estimation of recharge calculated through piezometric fluctuations and tritium of the water molecule were used as validation tools to confirm results generated by the GIS model which constitutes a useful tool to the delineation of recharge potential areas. The results which integrate several parameters into analyzing, are shown in figures 11,12.

It should be noted that there is a very good correlation between recharge rates estimated by quantitative approaches and potential areas generated by the GIS. For a better consistency in data interpretation, recharge rates calculated from quantitative methods were reclassified according to annual rainfall amount. Thus, the very low potentiality class represents $5 \%$ of annual rainfall; the low potentiality class represents $5-10 \%$; the moderate class $10-15 \%$; the good potentiality

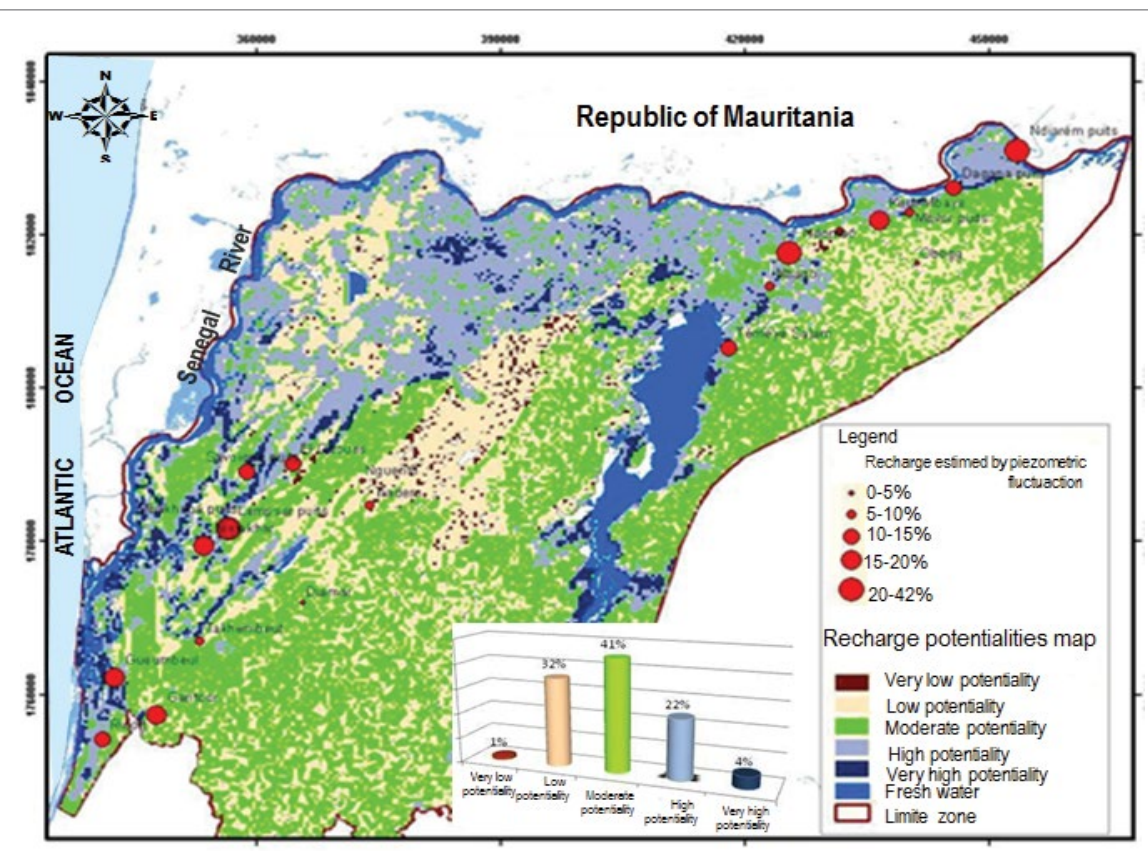

Figure 11: Classes of recharge determined from piezometric fluctuations superimposed on the aquifer potential map.

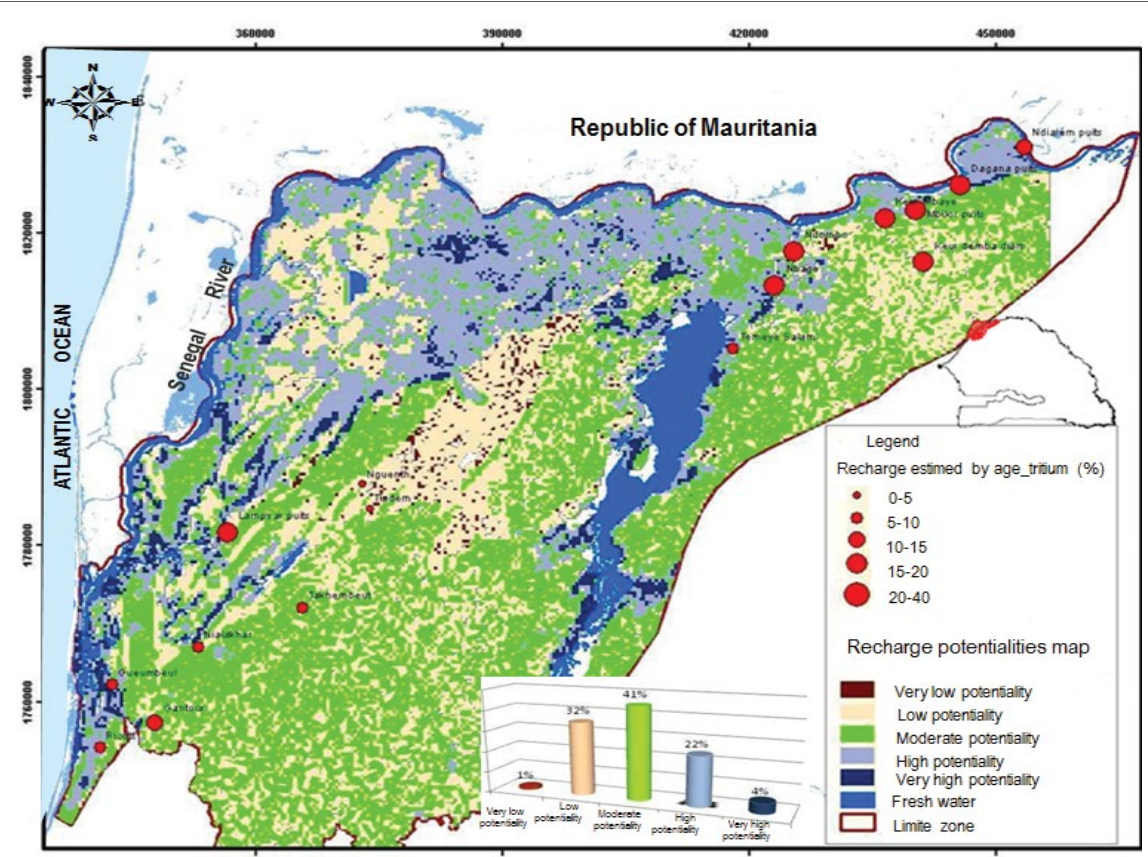

Figure 12: Classes of recharge determined from residence time of water Superimposed on the aquifer potential map. 
class represents $15-20 \%$ and the very good potentiality class is greater than $20 \%$ of annual precipitation. Recharge classes calculated from piezometric variations correspond perfectly with results of recharge potentialities mapping (Table 5).

Classes with good and very good potentialities are mainly found on approaches to hydraulic axes in the immediate vicinity of the irrigated zones and in the northeastern part of the zone corresponding to alluvial aquifer semi-permeable domain. It is also in these parts that we find the greatest possibility of alluvial aquifer recharge and therefore more opportunities to have a better quality of waters (TDS $<1000 \mathrm{mg} / \mathrm{L}$ ) mainly when it is close to river bank (river, lake, etc.) according to Diaw et al. (2016) [79]. These results were also supported by the modeling work carried out in the area by Filippi (1990) who considered that river bank infiltration contributions in hydraulics changes with alluvial aquifers are often restricted in the vicinity of streams and in irrigation channels. However, classes with moderate and low potentialities are mainly observed on dunes and in cuvettes with halomorphics oils. It can happen punctually, in some areas with moderate potential that high recharge rates can be observed. As is the case of Gant our well or conversely areas with high potential corresponding to low recharge rates to moderate (TiagoetTémèyeSalamwells) (Figure 11). This could be explained by balances sheet imbalances most often caused by external inputs from irrigation or greenhouse cultures, which are sometimes important locally in the dunes. But also, by high withdrawals for water supply of riparian populations which dispose of ground waters as only freshwater resources available. All these factors could have a direct impact on recharge calculations from piezometric fluctuations and thus favor theses light offsets. The combined analysis of recharge classes determined from the tritium of the water molecule on recharge potentialities mapping also shows very good correlations (Figure 12). These results also indicate that then or the astern part of the study zone (Guiers Lake and Dagana Basin) is an area with a higher potential for groundwater storage if we take into account results of GIS and recharge rates obtained. Thus, wells located in the alluvial plain along the rivers or near irrigated zones, are more productive and ground waters are relatively younger than those situated in the downstream part (South West). In this area, most of the flood plain remains to be excluded in the appropriate wells drilling site choice due to low recharge possibilities and poor quality of the ground waters (TDS $>5000 \mathrm{mg} / \mathrm{L}$ ), which are commonly salted. Thus, aquifer recharge could also increase ground waters and soils salinity issues $[27,33]$. The analysis of these results also indicates that in dune formations, the realization of drilling productive wells must require precise knowledge in the choice in the appropriate site. Because in these areas with moderate potentiality, the probability to have fresh water remains very high in Ogolian sediments. These sediments are characterized by low recharge possibilities when the thicknesss a dry layer is important (more than $10 \mathrm{~m}$ ). Dunes with moderate potential is a important reserve of fresh water, but with a limited quantity, that is why they are exploited only through hand dug well sorvillage wells. Thus, the future choice of wells drilling productive of significant freshwater quantities would be more judicious in the parts where the thickness of the sandy cover is low (zone close to the delta). This situation is favorable for groundwater recharge by direct infiltration of rainfall or lateral infiltration through river banks from surface water. The other explanation that could be given for these inconsistencies arising from the application of these methods may be also due to mapping processes that may alter results in some cases. Indeed, some data from the analysis as well as tools used could be responsible for these errors in results generated by the GIS. The efficiency of these predicted results will largely depend on the nature of the terrain (discontinuous and heterogeneous nature), the density of measurement points, the precision of interpolation methods, but especially the quality data used for analysis. For example, if we take the case of the depth which polarizes more weight than the other

Table 5: Results of TDS and recharge rates calculated from tritium contents.

\begin{tabular}{|c|c|c|c|c|c|c|}
\hline Name of wells & $\begin{array}{c}\text { TDS } \\
\text { (mg/L) }\end{array}$ & $\begin{array}{l}\text { Recharge }(\mathrm{mm} / \\
\text { year })=S y^{*} \mathrm{dh} / \mathrm{dt}\end{array}$ & $\begin{array}{c}\mathrm{Hi}=\text { groundwater } \\
\text { depth }\end{array}$ & ${ }^{3} \mathrm{H}$ contents (UT) & $\begin{array}{l}T=-17.93^{*} \\
\ln \left(\mathrm{At}_{\mathrm{t}} / \mathrm{AO}_{0}\right)\end{array}$ & $\mathrm{R}=\Sigma \mathrm{ni}{ }^{*} \mathrm{Hi} / \mathrm{T}$ \\
\hline Dagana & 3800 & 45 & 4.19 & 1.6 & 2.4 & 19.11 \\
\hline Ndiareme Puits & 143.4 & 82.5 & 3.08 & 2.6 & 2.4 & 22.70 \\
\hline Mbilor & 431 & 19.5 & 4.35 & 2.2 & 3.4 & 28.73 \\
\hline Keur Mbaye & 147.3 & 64.5 & 8.83 & 2.4 & 1.9 & 65.14 \\
\hline Ndombo & 603 & 118.5 & 4.04 & 3 & 1.4 & 61.13 \\
\hline Thiago & 285 & 24 & 5.28 & 1.9 & 1.4 & 27.37 \\
\hline Temeye Salam & 8610 & 48 & 3.38 & 0.9 & 4 & 35.11 \\
\hline Foss village & 6370 & 52 & 4.31 & 0.9 & 18.8 & 11.12 \\
\hline Nguent & 217 & 7.5 & 2.6 & 1.4 & 9.91 & 25.1 \\
\hline Tiadem & 6810 & 12 & 1.6 & 1.6 & 9.92 & 61.7 \\
\hline Gueumbeul & 6130 & 57 & 2.38 & 1.8 & 5.7 & 13.69 \\
\hline Gantour & 2200 & 62.5 & 8.95 & 0.9 & 18.82 & 18.82 \\
\hline Ricott & 4450 & 37.5 & 2.7 & 1 & 6.4 & 6.4 \\
\hline Obogg & 6090 & 26.8 & 20.92 & 0.2 & 53.71 & 92.8 \\
\hline Keur Demba Diam & 8390 & 70 & 11.15 & 1.7 & 31.25 & 37.3 \\
\hline JDieri & 2630 & 19.4 & 13.43 & 0.5 & 14.32 & 8.4 \\
\hline Diamar & 2550 & 29.3 & 9.5 & 1.6 & 16.42 & 58.4 \\
\hline Takhmbeut & 5250 & 47.5 & 4 & 1.3 & 7.72 & 29.9 \\
\hline Ndalakhar & 1815 & 60 & 6.07 & 0.7 & 14.32 & 35 \\
\hline Mbakhana & 1950 & 90 & 4.3 & 2.7 & 1.89 & 63.15 \\
\hline Lampsar & 1271 & 37.5 & 10.22 & 0.7 & 26.75 & 46.5 \\
\hline
\end{tabular}

Citation: Diaw M, Mall I, Faye S, Travi Y (2018) Recharge Potentials Mapping using Remote Sensing and GIS Techniques: Case of Shallow Aquifers in the Senegal River Delta. J Environ Toxicol Stud 2(2): dx.doi.org/10.16966/2576-6430.117 
factors in the analysis, the accuracy of the map depends on the density of measuring points and the precision of interpolation methods. That is why it is necessary to quantify the uncertainty surrounding maps produced by multicriteria GIS in order to minimize the man to evaluate better the results.

\section{Conclusion}

This study demonstrated that using remote sensing techniques and multicriteria analysis of GIS, has allowed producing recharge potential maps by integrating various factors which contribute to groundwater recharge in the Senegal River Delta Hydro system. These maps show a qualitative and visual representation of recharge potentialities, which are validated by recharge rates estimated from piezometric fluctuations and tritium contents of groundwater in shallow aquifers. Thus, the comparison of results from recharge potentialities map and recharge classes determined from estimates method has shown a good correlation in the whole area. Despite some sites, where predicted recharge potentialities are not in line with calculated recharge rates. This is often related either to application limits of methods used, to precision margins of certain parameters taken into account in recharge calculations, or to results of mapping processes that may be altered by a number of factors that may affect the accuracy of the analysis. The advantage of the cartographic method is due to its simplicity and the accessibility of the parameters included in the analysis. In terms of hydro geological information, this is a method that can be very useful and could thus be applied to other sites whose hydro geological characteristics are similar. There charge potentialities map produced here is an important element for defining models for the management of groundwater resources and strategies for their sustainable exploitation but also for guiding well drillings site in the shallow aquifers in SRDH.

\section{References}

1. Michel P (1957) Rapport préliminaire sur la géomorphologie de la vallée alluviale du Sénégal et de sa bordure. Bull. MAS, Saint Louis, 111: 85 .

2. Maymard J (1960) Etudes pédologiques dans la vallée du Sénégal. Saint- Louis, MAS, bulletin 112: 38.

3. Tricart J (1961) Notice explicative de la carte géomorphologique du delta du Sénégal. Paris. BRGM. Inénl, 8: 118.

4. IRAT (1969) Recherches rizicoles en Casamance rapport annuel, institut de recherches agronomiques tropical et des cultures vivrières au Sénégal.

5. SEDAGRI (1975) Carte Pédologique et géomorphologique de la valléedudeltadu Sénégalau1/50000etcarted'aptitude cultural edesterresau 1/50000. OMVS-PNUD-FAO. Paris 70 feuillecouleurs+étudespédologique (texte) 252p.

6. Michel P (1973) Les bassins des fleuves Sénégal et Gambie. Étude géomorphologique. Mémoire ORSTOM no 63, 3: 752.

7. Michel P, Durand JM (1978) La vallée alluviale du Sénégal (Afrique de l'ouest). Relation géomorphologie- sols-aptitudes culturales et leur cartographie au 1/50000.Catena, 5.2: 213-225.

8. Lebrusq JY, Loyer JY (1983) Evolution de la salinité des sols et des eaux en relation avec la riziculture submergée dans le delta du fleuve Sénégal, Multigr. ORSTOM Dakar 16 pages.

9. Loyer JY (1989) les sols salés de la basse vallée du fleuve Sénégal. Edition de I'ORSTOM. Collection Études et Thèses, Paris, France 137p.
10. Mission d’Aménagement du Sénégal (MAS) (1956-1959) Plan général d'aménagement de la vallée du fleuve Sénégal: proposition pour l'aménagement du fleuve et nouvelles propositions pour l'aménagement du fleuve Sénégal, rapports volumineux, subdivision Richard Toll, travaux no 1 and 2, Sénégal.

11. SAED (1965) Programme de mise en valeur du fleuve Sénégal avec, comme formule de développement, le paysannat coopératif.

12. BRGM (1956) Géologie de la region de Richard Toll (Sénégal). Auteur Degallier R, arch.BRGM, Dakar, 18pp. Miméo.

13. Audibert M (1967) Delta du fleuve Sénégal:Étude géologique. Rapport du projet AFR- REG-61 (Saint Louis), 4 volumes.

14. Audibert M (1970) Delta du fleuve Sénégal. Étude hydrogéologique. Projet hydro-agricole du bassin du fleuve Sénégal. Tome III: hydrogéologie, Tome IV: drainabilité, Rapport Projet AFR/REG 61. FAO/OERS.

15. Michel P, Elouard P, Faure H (1968) Nouvelles recherches sur le quaternaire récent de la région de Saint Louis (Sénégal). Bull. IFAN. T.XXX. sér. A no 1. p.231-234. 1 carte.

16. EQUESEN (Environnement et Qualité des Eaux au Sénégal) (19901991) Environnement et qualités des eaux souterraines: collectes des données piézométriques, projet $\mathrm{n}$ rS2-/0198-FBD.

17. Illy P (1973) Étude hydrogéologique de la vallée du fleuve Sénégal. Projet hydro agricole du bassin du fleuve Sénégal. Rapport RAF/65061, 158P.

18. SEDAGRI (1970) Étude Hydro Agricole Du Bassin Du Fleuve Sénégal. Étudepédologique. Résumé Et Conclusions Générales. Paris, 106.

19. SEDAGRIFAO (1973) Étude Hydro Agricole Du Bassindu Fleuve Sénégal. Étudepédologique. SEDAGRI. Paris, France.

20. Monteillet J (1980) Le quaternaire du delta : Synthèse des connaissances actuelles avec de nouvelles données sur l'Holocène. Bull. I.F.A.N. Tome 41. Série A. no1. Janvier 1979 Dakar.

21. Monteillet J (1988) Environnement sédimentaire et paléoécologie du Delta du Sénégal au quaternaire: évolution d'un écosystème fluviomarin tropical au cours des derniers cent mille ans. Laboratoire de recherche de sédimentologie marine. Université de PerpignanThèse de Sciences Naturelles. 267 pp.

22. OMVS/USAID (1990) Rapport de synthèse hydrogéologique du delta du fleuve Sénégal. Projet OMVS/USAID 625-0958. Eaux souterraines. Rapport final. Dakar. Sénégal. Volume II. P 73 et annexes.

23. ANSD (2014) Recensement Général de la Population et de I'Habitat, de l'Agriculture et de l'Elevage (RGPHAE). République du Sénégal Ministère de l'Economie, des Finances et du Plan.

24. Tricart J (1954) Influence des sols salés sur la déflation éolienne en basse Mauritanie et dans le delta du Sénégal. Ser. Geom. Dyn. tom.5. no 3. 124-132.

25. Raes D, Deckers J (1993) Les sols du Delta du fleuve Sénégal Propriétés Physiques et Chimiques. Projet Gestion de l'Eau, Bulletin Technique $n \bullet 8,1993$. SAED-Centre de NDiaye, Saint-Louis, Sénégal.

26. Gning A Aziz (2015) Etude et Modélisation Hydrogéologique des Interactions Eaux de Surface-Eaux Souterraines dans un Contexte d'Agriculture Irriguée dans le Delta du Fleuve Sénégal, Thèse de doctorat, pp 230+ annexes.

27. Diaw M, Mall I, Sane S, Madioune HD, Faye S (2015) Assessing of the Suitability for Irrigation Water and Their Repercussions on Land Degradation Process in Delta and Lower Senegal River Valley. Am J Water Resour 3: 32-43. 
28. Dielman P J (1969) Rapport de consultant du projet d'étude hydro agricole du bassin du fleuve du Sénégal (inédit)

29. Touzi S (1998) Formalisation des échanges fleuve-nappe en présence de zones d'inondation, cas de la régularisation des crues du fleuve Sénégal. DEA Sciences de l'Eau dans l'Environnement Continental. ORSTOM, ENGREF, Dakar, Sénégal, 101.

30. Da Boit M (1993) Impact des aménagements hydro-agricoles sur la nappe superficielle de la basse vallée du fleuve Sénégal (ThiagarRichard-Toll-Dagana). DEA Géologie appliqué Hydrogéologie. FSTUCAD, 1 - 94.

31. Diagana A (1994) Études hydrogéologiques dans la vallée du fleuve Sénégal de Bakel à Podor: Relation eaux de surface/eaux souterraines. Thèse de Doctorat de 3eme cycle. Géologie appliquée: Mention Hydrogéologie; FST-UCAD. 127 pages et annexes.

32. Bâ M (1997) Les eaux estuariennes du fleuve Sénégal: Impact des barrages de Diama et de Manantali. In: Rapport technique CRDI, Eaux estuariennes/Sénégal, Dakar, no89-0074, 59p, 41 fig, 6 tab, 4 ph.

33. Faye S, Diaw M, Ndoye S, Malou R, Faye A (2009) Groundwater recharge and salinization in Senegal coastal semiarid regions: Groundwater and Climate in Africa Proceedings of the Kampala Conference, June 2008, IAHS Publ 334: 163-173.

34. Diaw M (2008) Approche hydrochimique et isotopique de la relation eau de surface/nappe et du mode de recharge de la nappe alluviale dans l'estuaire et la basse vallée du fleuve Sénégal: Identification des zones inondées par Télédétection et par traçage isotopique, Mem. de Doctorat de Thèse 3e cycle FST/UCAD de Dakar, $210 p$

35. Jha MK, Chowdhury A, Chowdary VM, Peiffer S (2007) Groundwater management and development by integrated remote sensing and geographic information systems: prospects and constraints. Water Resour Manage 21: 427-467.

36. Bahuguna IM, Nayak S, Tamilarsan V, Moses J (2003) Groundwater prospective zones in basaltic terrain using remote sensing. J Indian Soc Remote Sens 31: 107-118.

37. Das S, Behra SC, Kar A, Narendra P, Guha NS (1997) Hydrogeomorphological mapping in ground water exploration using remotely sensed data-a case study in keonjhar district, Orissa. J Indian Soc Remote Sens 25: 247-259.

38. Stafford DB (1991) Civil engineering applications of remote sensing and Geographic Information Systems. ASCE, New York.

39. Krishnamurthy J, Venkatesa N, Jayaraman V, Manivel M (1996) An approach to demarcate ground water potential zones through remote sensing and geographical information system. Int J Remote Sens 17: 1867-1884

40. Saraf AK, Choudhury PR (1998) Integrated remote sensing and GIS for groundwater exploration and identification of artificial recharge sites. Int J Remote Sens19: 1825-1841.

41. Teeuw RM (1995) Groundwater Exploration Using Remote Sensing and A Low-Cost Geographical Information System. Hydrogeol J 3: 21-30.

42. Tiwari A, Rai B (1996) Hydrogeological Mapping for Groundwater Prospecting using Land sat-MSS Images-A Case Study of part of Dhanbad District, Bihar. J Indian Soc Remote Sens 24: 281-286.

43. Goyal S, Bhardwaj RS, Jugran DK (1999) Multicriteria Analysis using GIS for Groundwater Resources Evaluation in Rawasen and Pili Watershed, Uttar Pradesh. Proceedings Map India 99, New Delhi, India.
44. Jaiswal RK, Mukherjee S, Krishnamurthy J, Saxena R (2003) Role of remote sensing and GIS techniques for generation of groundwater prospect zones towards rural development--an approach. Int J Remote Sens 24: 993-1008.

45. Al Saud M (2010) Mapping potential areas for groundwater storage in Wadi Aurnah Basin, western Arabian Peninsula, using remote sensing and geographic information system techniques. Hydrogeol J 18: 1481-1495.

46. Elewa HH, Qaddah AA (2011) Groundwater potentiality mapping in the Sinai Peninsula, Egypt, using remote sensing and GIS-watershedbased modeling. Hydrogeol J 19: 613-628.

47. Abdallah F (2012) Mapping of groundwater prospective zones using remote sensing and GIS techniques: A case study from the Central Eastern Desert, Egypt. J Afr Earth Sci 70: 8-17.

48. Obi Reddy GP, Chandra Mouli K, Srivastav SK, Srinivas CV, Maji AK (2000) Evaluation of Ground Water Potential Zones Using Remote Sensing Data -A Case Study of Gaimukh Watershed, Bhandara District, Maharashtra. J Indian Soc Remote Sens 28: 19-32.

49. Pratap K, Ravindran KV, Prabakaran B (2000) Groundwater Prospect Zoning Using Remote Sensing and Geographical Information System: A Case Study in Dala-Renukoot Area, Sonbhadra District, Uttar Pradesh. J Indian Soc Remote Sens 28: 249-263.

50. Singh AK, Prakash SR (2002) An integrated approach of remote sensing, geophysics and GIS to evaluation of groundwater potentiality of Ojhala subwatershed, Mirzapur district, U.P.

51. Sreedhar G, Vijaya Kumar GT, Murali Krishna IV, Ercran K, Demirel MC (2009) Mapping of groundwater potential zones in the Musi basin using remote sensing data and GIS. Adv Eng Softw 40: 506 518.

52. Mall I, Diaw M, Madioune HD, Ngom PM, Faye S (2014) Use of Remote Sensing and GIS for Groundwater Potential Mapping in Crystalline Basement Rock (Sabodala Mining Region Senegal). Nova Science Publishers Inc.

53. Mohammed Aslam MA, Balasubramanian A, Kondoh A Rokhmatuloh R, Mustafa AJ (2003) Hydrogeomorphological mapping using remote sensing techniques for water resource management around palaeochannels. Proceedings of the 2003 IEEE International, Toulouse, France, 5: 3317-3319.

54. Srinivasa Rao Y, Jugran KD (2003) Delineation of groundwater potential zones and zones of groundwater quality suitable for domestic purposes using remote sensing and GIS. Hydrogeol Sci J 48: 821-833.

55. Chowdhury A, Jha MK, Chowdary VM, Mal BC (2009) Integrated remote sensing and GIS-based approach for assessing groundwater potential in West Medinipur district, West Bengal, India. Int J remote sens 30: 231-250.

56. El-kadi Al, Oloufa AA, Eltahan AA, Malic HU (1994) Use of a Geographic Information System in Site-Specific Ground-Water Modeling. Ground Water 32: 617-625.

57. Jacob Novaline, Saibaba J, Prasada Raju PVS, P (1999): Groundwater modelling for sustainable development using GIS techniques. Preconference volume 264-267 Geoinformatics Beyond 2000, Dehradun, India.

58. Shahid S, Nath SK, RoyJ (2000) Groundwater potential modelling in a soft rock area using a GIS. Int J Remote Sens 21: 1919-1924.

59. Boutt DF, David WH, Bryan CP, David TL (2001) Identifying Potential Land Use-Derived Solute Sources to Stream Baseflow Using Ground Water Models and GIS. Ground Water 39: 24-34. 
60. Saraf AK, Choudhury PR, Roy B, Sarma B, Vijay S, et al. (2004) GIS based surface hydrological modelling in identification of groundwater recharge zones. Int J Remote Sens 25: 5759-5770.

61. Sisay L (2007) Application of Remote Sensing and GIS for Groundwater Potential Zone Mapping in Northern Ada'a Plain (Modjo Catchment). Addis Ababa University, Addis Ababa-1176, 77p.

62. Rokade VM, Kundal P, Joshi AK (2007) Groundwater Potential Modelling through Remote Sensing and GIS: A Case Study from Rajura Taluka, Chandrapur District, Maharashtra. J Geol Soc India 69: 943-948.

63. Corsiki A, Cervi F, Ronchetti F (2009) Weight of evidence and artificial neural networks for potential groundwater spring mapping: an application to the Mt. Modino area (Northern Apennines, Italy) Geomorpholgy 111: 79-87.

64. Chenini I, Mammou AB, May ME (2010) Groundwater Recharge Zone Mapping Using GIS-Based Multi-criteria Analysis: A Case Study in Central Tunisia (Maknassy Basin). Water Resour Manag 24: 921939.

65. Gupta M, Srivastava PK (2010) Integrating GIS and remote sensing for identification of groundwater potential zones in the hilly terrain of Pavagarh, Gujarat, India. Water Int 35: 233-245.

66. Rahman MA, Rusteberg B, Uddin MS, Lutz A, Saada MA, et al. (2013) An integrated study of spatial multicriteria analysis and mathematical modelling for managed aquifer recharge site suitability mapping and site ranking at Northern Gaza coastal aquifer. J Environ Manag 124: 25-39.

67. Kumar MG, Bali R, Agarwal AK (2009) Integration of remote sensing and electrical sounding data for hydrogeological exploration-a case study of Bakhar watershed, India. Hydrol Sci J 54: 949-960.

68. Yeh HF, Lee $\mathrm{CH}$, Hsu KC, Cheng PH (2009) GIS for the assessment of ground water recharge potential zone. Environ.Geol 58: 185-195.

69. Kankou OM (2004) Vulnérabilité des eaux et des sols de la rive droite du fleuve Sénégal en Mauritanie. Étude en laboratoire du compartiment de deux pesticides. Chimie et microbiologie de l'eau. These de 3ème cycles. Univ. de Limoges. p159.

70. Elouard $P$ (1962) Étude géologique et hydrogéologique des formations sableuses du Cuebla mauritanien et de la vallée du Sénégal. Thèse es Doctorat Science Paris. Doctorat et Mem. BRGM 7: $250 \mathrm{p}$.

71. Faure H, Elouard P (1967) Schéma de variations du niveau de l'océan Atlantique sur la côte de l'Ouest bot. France, 100, p. 153 158. Inst. fond. Afr. noire, A, 2013, 809-868.

72. Michel P, Sall M (1984) Dynamique des paysages et aménagement de la vallée alluviale du Sénégal. Écologie et développement 6: 89109.

73. Deckers J, Raes D, Ceuppens J, Dewachter I, Merckx R, et al. (1996) Evolution de l'acidité dans les sols du delta du fleuve Sénégal sous l'influence anthropogène. Etude et Gestion des Sols 3: 151-166.

74. Darling WG, Bath AH (1988) A stable isotope study of recharge processes in the English Chalk. J Hydrol 101: 31-45.

75. Thatcher L, Janzer VJ, Edwards RW (1977) Methods for determination of radioactive substances in water and fluvial sediments. In: Techniques of Water-Resources Investigations of the US Geological Survey. US Government Printing Office. Washington DC, 79-81.

76. Rhuston (1988) Numerical and Conceptual Models for Recharge Estimation in Arid and Semi-Arid Zones. In: Estimation of Natural Ground water Recharge. NATOASI Series book series, 223-238.

77. Sukhija BS, Reddy DV, Nagabhushanam P, Hussain S (2003) Recharge processes: piston flow vs preferential flow in semi-arid aquifers of India. Hydrogeol J 11: 387-395.

78. Silverman BW (1986) Density Estimation for Statistics and Data Analysis. Routledge, NewYork, USA.

79. Diaw M, Wade S, Faye S (2016) Géochimie et contexte d'écoulement des eaux:Delta du fleuve Sénégal : Pertinence des traceurs chimiques et isotopiques et des images optiques dans l'étude des inondations, Verlag/Editeur: Presse Académique Française, 214P. 